Scientific Journal of Informatics

Vol. 4, No. 2, November 2017

p-ISSN 2407-7658 http://journal.unnes.ac.id/nju/index.php/sji

e-ISSN 2460-0040

\title{
The Analysis of Implementation Business Model Canvas At The E-Marketplace Dipeta Company
}

\author{
Ni Wayan Purnawati ${ }^{1}$, Djoko Budiyanto Setyohadi ${ }^{2}$ \\ ${ }^{1,2}$ Magister Informatics Engineering, Universitas Atma Jaya Yogyakarta, Yogyakarta, Indonesia \\ Email: 1niwayan.purna@gmail.com, 2djoko.bdy@gmail.com
}

\begin{abstract}
In the internet Era as now everything is easily accessible, obtaining good information, education, services even trade. E-Marketplace as a new innovation for interaction between buyer and seller can also encourage micro medium to promote his business. www.pesansaja.com released by dipeta in the field of E-Marketplace of local culinary, which still require a lot of innovation to be able to attract customers and keep them. Innovation is also needed to be able to compete with other competitors on the E-Marketplace that engaged in the same. Hence the need for the implementation of the business model Canvas is the next generation business model to suit the wishes of the customer and an evaluation based on the strengths and weakness owned by the company in the form of SWOT analysis. The results of the Analysis implementation are expected to make the company's E-Marketplace is getting big and compete at a national level as an E-Marketplace of successful culinary attract customers.
\end{abstract}

Keywords: Business Model Canvas, E-Marketplace, Relationship

\section{INTRODUCTION}

The existence of the internet makes the trading system. With the advancement of internet trading system evolved into conventional electronic commerce (e-commerce). Along with that e-commerce is evolving into, various types of business such as business-to-business (B2B), business-to-customer (B2C), customer-to-customer (C2C), or business-to-business-to-customer (B2B2C).Large sales opportunities can be obtained through technology that integrates as an E-marketplace. This is because a great trust from the consumer to the seller. The role of intermediaries (as EMarketplace) from the trader to the consumer is very important [1]. Consumers are very loyal and have intention to buy if the mediator may hold fast to the principle of work and maintain its quality as an intermediary.To be able to keep customers, business evaluation needs to be done so. Approach business model canvas is the most popular approach is often used firms. Business model canvas can show the characteristics of the company into several categories [2]. This can help provide insight towards the stakeholders for develop the company.

At this time, including the e-growing local marketplace in Yogyakarta. Dipeta is a company specialized in the online delivery of food companies who work with food outlets in Yogyakarta. In running its business Dipeta little by little, potentially becoming a successful online company and can compete nationally. However, to 
make this Dipeta need to do an evaluation of the E-Marketplace for can keep up its customers in the future.This article discussed the business model of the company's business plan as an approach in the future. By using a business model canvas at the emarketplace in Yogyakarta.

\section{METHODS}

\subsection{Dipeta Company Profile}

The company Dipeta is an e-marketplace service, which offers culinary delivery of meals ready to eat and the gift shop go directly to customers. Dipeta company is working with the restaurant's outlets, even Street outlets to promote their food menu. Customers can use the menu and choose what they want by a catalogue of existing outlets, can then choose the menu and the number of servings needed.

Dipeta companies implementing systems for results with outlets that work together with the company Dipeta for the result is determined according to agreement with. Emarketplace this gives advantages for outlets in cooperation among them that is able to get closer to consumers, cost-effective, getting media promotion, free of cost, care and high standard quality shown as Table 1 .

Table 1. Company Profile E-Marketplace

\begin{tabular}{l|l}
\hline & PT.Dipeta \\
Www.pesansaja.com \\
Company name \\
$\begin{array}{l}\text { Site } \\
\text { Company Location }\end{array}$ \\
The Slogan & Click and up \\
Site Language & Indonesia \\
Launch Date & May, 2014 \\
Visitor until sept 2014 & 2.423 .000 \\
Total Pages Opened & 15.548 .000 (in 2014, Sept) \\
The average visit & $5-15$ Minute/visit
\end{tabular}

To know the development of the company, this article is also in the show data visitors or consumers of in the city of Yogyakarta. Data obtained from the website www.pesansaja.com.

Table 2. Visitor Profile Data (data 2016, Nov)

\begin{tabular}{lr|c}
\hline & $\begin{array}{c}\text { Visitor Precentage } \\
(\boldsymbol{\%})\end{array}$ \\
\hline Age Range & $<20$ & 10 \\
& $20-40$ & 70 \\
& $<40$ & 20 \\
\hline
\end{tabular}




\begin{tabular}{|c|c|c|}
\hline \multicolumn{3}{|l|}{ Gender } \\
\hline & Male & 90 \\
\hline & Female & 10 \\
\hline \multicolumn{3}{|l|}{ Education } \\
\hline & D3 & 20 \\
\hline & D3/S1 & 70 \\
\hline & $>\mathrm{S} 1$ & 10 \\
\hline \multicolumn{3}{|c|}{$\begin{array}{l}\text { Jobs (visitors/Consumers in the city of } \\
\text { Yogyakarta) }\end{array}$} \\
\hline & \multirow{4}{*}{$\begin{array}{r}\text { Private Employees } \\
\text { Self employed } \\
\text { Civil servant } \\
\text { Students }\end{array}$} & 20 \\
\hline & & 10 \\
\hline & & 10 \\
\hline & & 60 \\
\hline \multicolumn{3}{|c|}{$\begin{array}{l}\text { Best-selling product types (visitors/Consumers in } \\
\text { the city of Yogyakarta) }\end{array}$} \\
\hline & \multirow{3}{*}{$\begin{array}{r}\text { Fast Food } \\
\text { Gift Shop } \\
\text { Snack \& Bakery }\end{array}$} & 70 \\
\hline & & 15 \\
\hline & & 15 \\
\hline
\end{tabular}

\subsection{E-Marketplace}

E-Marketplace is a virtual market place during the buying and selling and exchanging information between buyers and sellers [3] exist the internet as it is now it makes EMarketplace integrates with web-based technologies to conduct business transactions. Marketplace with internet technology using rules or standards in distributing data products and in terms of service [4]. E-Marketplace is where business transactions online using web-based as an intermediary. With the E-Marketplace buyers can find sellers of a product with the criteria and the price is in want. The contrary neither the provider of services or products can show the consumers who need their services or products.

The success of an E-Marketplace is a net profit is obtained from the seller or supplier. While there are certainly buyers on products obtained at an affordable price. Products at low prices is usually compared to the price of products derived from traditional markets.

In this case the E-Marketplace as a third-party can be trusted by consumers. Consumers will be loyal in service of process on the online transactions in the process of with either [1]. In addition to be able to compete with other E-Marketplace is an EMarketplace that either need to do check the business. So E-Marketplace can do success profits with consumers. 


\subsection{Business Model Canvas}

Business models are formed over a framework concept for can expose a business construction enclosing environment, innovation, Strategy, and Performance of a company [5]. It is important to show in the company about its business performance to keep competing support business. Innovation needed to adjust to environmental conditions and progress at this time. In this case the E-Marketplace as the innovation of the environment industry in trade greatly help give in giving a much value for customers or businessmen.

Barquet, Oliveira, Amigo, Cunha, \& Rozenfeld [6] applying the business model canvas for improving the services of the service product. Framework on business model canvas helps to develop guidelines on the company. In addition to assisting in develop the service system. This framework also can guide towards the analysis of the characteristics of companies that will be developed.

Osterwalder \& Pigneur [7], dividing the outline into 9 block as follow

1) Customer Segments: Customer segment has a customer who works closely with the company.

2) Value Propositions: In this section trying to figure out the problem and what the desired customer value proposition.

3) Channels: This section seeks to find the roles that are associated with the value proposition as communication, sales, and delivery.

4) Customer Relationship: In this section the company can figure out how to connect or keep customers.

5) Revenue Streams: The company can figure out how to profit to be gained with this new business.

6) Key Resources: Companies can know the resources that work for business operations.

7) Key Activities: In this section the company can know the level of the main activity of the business.

8) Key Partnership: Companies can know the relationship of cooperation that intertwined with the company.

9) Cost Structure: In this section the company can know what fee structure needed in this business.

This research uses the framework osterwalder, where that section 9 can represent business concepts that will be planned for the company Dipeta.

\subsection{Swot Analysis}

SWOT (strength, weak, opportunities, Threats) focus to find out the company's current situation. the company's latest conditions include linkages to environmental and social $[8]$. 


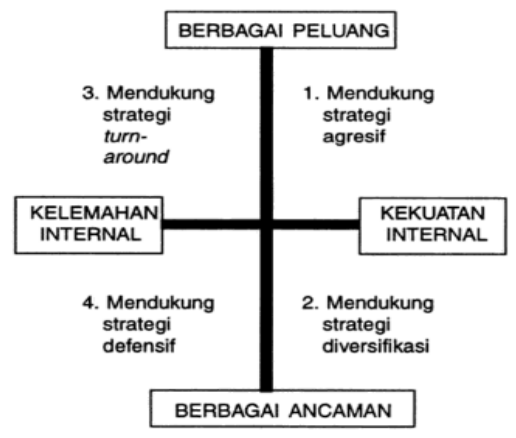

Figure 1. Framework of A SWOT Analysis

In this case, the SWOT technique is concerned with planning, strategy, vision, and mission of the company, of course, in this case a SWOT analysis will lower even end exist threats and weaknesses. On the SWOT of research designed to find out which company it is of course obtained based on the interview against the owner of the EMarketplace Dipeta companies.

A SWOT analysis can help the research to know the strengths, weaknesses, opportunities and threats of the situation the company dipeta now. So the evaluation of these SWOT analysis can be advice on the business model canvas framework.

\subsection{The Analysis of Empathy Map}

The folder provides analysis of Empathy about the proportion of the value of what is already by what the customer wants or not [9]. Not a lot of research that uses the folder empathy as analysis. Mostly just a mapping directly at an object.

And the image retrieved from an interview someone about what they feel. Simple Empathy Folder help knowing what felt, heard, done, and what is thought of by the customer. Empathy folder can analyze the aspirations of environment, desires, habits of a consumer with different profiles.

\subsection{Research Methodology}

\subsubsection{Qualitative Research}

This case study uses qualitative methods of research as a method. In this case all problems involving a social phenomena, cultural conflict and social interaction requires a deep analysis using several techniques to get data like interviews, case studies, surveys, and observations.

\subsubsection{Research Focus}

On qualitative research, the authors focus more on class needs and the purposes of the 
issue will be solved. The focus of the research in this study is to find out how the condition of E-Marketplace Dipeta companies who are already running at the moment and how to start it into the framework of the categories contained on the Business Model Canvas. It is for getting the new business model would be developed on the company's E-Marketplace Dipeta.

\subsubsection{Sources and Types of data}

The main source of data collection on qualitative research and activity is obtained through interviews with informants. While other data obtained through the physical data in the form of archives, documents, or other images. For this type of data in this study were collected from two types of research data, which are:

1. Primary Data

Primary data were obtained from interviews with informants who was directly involved in the work. Either the owner of the company Dipeta, or users of the EMarketplace.

2. Secondary Data

Research on secondary data obtained from earlier research, reference book, reference, documentation, either physical or literature relevant to the research

\section{RESULTS AND DISCUSSION}

\subsection{SWOT Analysis}

Swot result in figure 2 based on research conducted through interviews and observations on the site e-marketplace www.pesansaja.com.

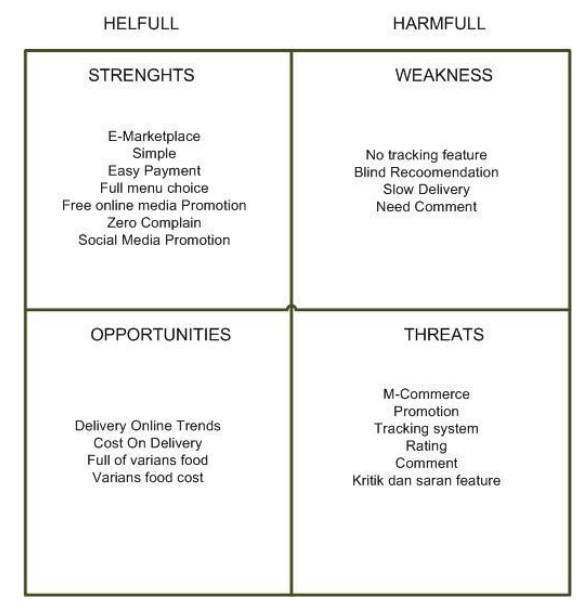

Figure 2. SWOT analysis on E-Marketplace www.pesansaja.com

1) Strength

The power in this business is a business that is simple yet very required, flexible payment Convenience, menu options are many, e-marketplace also gives free promo 
for his media outlets, the e-marketplace that receive customer complain, making social media as well as promotion.

\section{2) Weakness}

The weakness of the existing e-business marketplace, there is a lack of some features such as order tracking so customers know the extent to which orders are delivered, the system is also less food recommendations which became the favorite in the form of comments or rating outlets, then this business also has a disadvantage rather slow in responding to the order.

\section{3) Opportunities}

Opportunities can be obtained from the e-marketplace is that the delivery system is the trends that were hits at this time. Neither cost in delivery is the trends that occur at this time, this business offers a varied menu with prices that vary also.

\section{4) Threats}

Threats that can give impact on the customer relationship at the E-marketplace is the existence of competition, less promotion, lack of tracking system for order can also make an impact on the customer relationship, as well as the lack of comments feature for entries or lack of space to give feedback on the E-marketplace.

\subsection{Emphaty Map Analysis}

Analysis of empathy folder on the E-marketplace is in the analysis based on the view of one Potential Customer. Potential Customer data obtained from companies where the most numerous among the students who reserve in Figure 3.

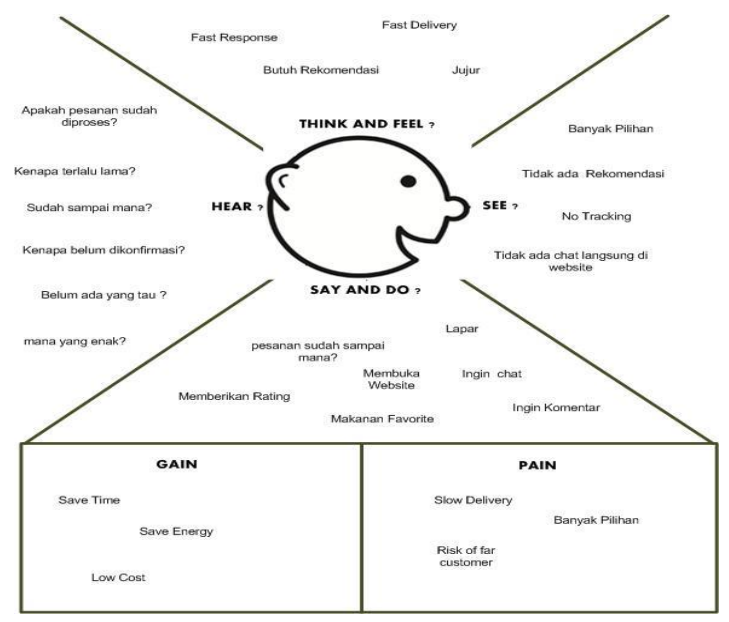

Figure 3. The analysis Folder Empathy E-Marketplace www.pesansaja.com Our customer is a student of the IT spend more than 8 hours per day for online and often do food delivery order. Factors that are present in the map of empathy that is: 
1) Factors Hear

This cause more explicate what customer heard from neighbors about the performance of the system E-marketplace. Examples include exist many EMarketplace that does not yet know whether orders already processed or not, or when it's ordered customers heard already up to where the current order.

2) think and feel

This reason expresses what the customers think and feel toward the performance of the system, such as rapid response service, food recommendations, as well as select food then.

3) Factors see

This cause expresses what the customer view of the E-marketplace system, in this case such as: the large number of available options can create customer confusion select menus and need recommendations, then the customer also see no chat feature on the system E-marketplace to ask information directly.

4) A cause of say and do

A cause of say and do is the customer spoke and acted against the system of Emarketplace in this example as when the customer feels hungry, and then open the customer website, until the customer gets a favorite food.

\subsection{Implementation Method of the Canvas}

As already explained earlier that the results of evaluations already carried out will be the main basis of make new business models in the E-Marketplace in Figure 4.

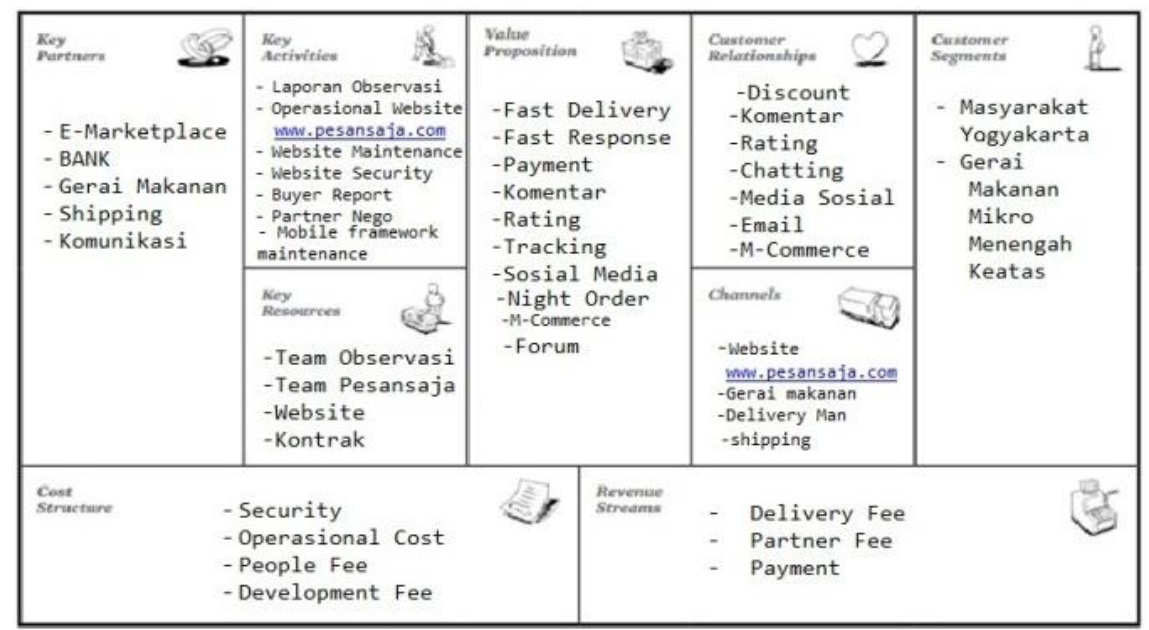

Figure 4. Apply Business Model Canvas at the E-Marketplace www.pesansaja.com

On apply the visible some visible 9 main block already has thought-provoking concept of how an E-marketplace can innovate new business models with integrated evaluation - evaluation is done before. The company may make changes to dipeta of course it already described the thinking of the customer (empathy Map) and the company's current situation (SWOT). 


\section{CONCLUSION}

The results of this research can answer the problem formulation to form new business models and provide recommendations where researchers can close that E-Marketplace that already run when it still need a lot of innovation to develop the business. This gives implications on the company to be able to keep customers do order. Business model Canvas that is already applied to the E-Marketplace www.pesansaja.com can be applied as a new business model because it applied based on SWOT evaluation and evaluation of the potential customers. Feedback or suggestions can be included in this research was the need for a complete data evaluation on empathy folder to find out the thinking of the agent, of course as well as retaining customers can also compete with other competitors.

\section{REFERENCES}

[1] Hong, I.B. \& Cho, H. 2011. The impact of consumer trust on attitudinal loyalty and purchase intentions in B2C e-marketplaces: Intermediary trust vs. seller trust. International Journal of Information Management, Vol. 31(5), pp.469479.

[2] Tanev, S., Rasmussen, E.S. \& Hansen, K.R. 2016. Business plan basics for engineers. Start-Up Creation: The Smart Eco-efficient Built Environment, pp.21.

[3] Segev, A., Gebauer, J. and Färber, F., 1999. Internet-based electronic markets. Electronic Markets, Vol. 9(3), pp.138-146.

[4] Nathan, R., 2001. E-Marketplaces: new challenges for enterprise policy, competition and standardisation. In Workshop Report, Brussels.

[5] S. Manurung and L. Dr., Strategi dan Inovasi Model Bisnis Meningkatkan Kinerja Usaha, Jakarta: Elex Media Komputindo, 2010.

[6] Barquet, A.P.B., de Oliveira, M.G., Amigo, C.R., Cunha, V.P. and Rozenfeld, H., 2013. Employing the business model concept to support the adoption of product-service systems (PSS). Industrial Marketing Management, Vol. 42(5), pp.693-704.

[7] A. Osterwalder and Y. Pigneur, Business Model Generation, Amsterdam: Modderman Drukwerk, 2009.

[8] F. Rangkuti, Analisis Swot Teknik Membedah Kasus Bisnis, Jakarta: Gramedia Pustaka Utama, 2006. 